\title{
PENGARUH INSENTIF TERHADAP KINERJA PENGEMUDI GRAB BIKE DI KOTA KUPANG
}

\author{
Agnes Nati $^{1}$, Tarsisius Timuneno ${ }^{2}$, Rolland E. Fanggidae ${ }^{3 *}$ \\ 1,2,3Universitas Nusa Cendana, rolland_fanggidae@staf.undana.ac.id \\ *(Corespondance Author)
}

\begin{abstract}
ABSTRAK
Penelitian ini bertujuan untuk mengetahui pengaruh insentif terhadap kinerja pengemudi Grab Bike di Kota Kupang. Penelitian ini merupakan penelitian asosiatif dengan menggunakan dengan menggunakan pendekatan kuantitatif. Teknik pengumpulan data dilakukan dengan menyebarkan kuesioner, melakukan observasi serta wawancara. Teknik analisis data yang digunakan dalam penelitian ini adalah regresi linear sederhana. Penelitian ini dilakukan pada para pengemudi Grab Bike di kota Kupang dengan sampel sebanyak 83 pengemudi. Hasil analisis data menunjukan bahwa Insentif berpengaruh positif terhadap kinerja pengemudi Grab Bike di kota Kupang. Temuan tersebut dapat menjadi bahan evaluasi manajemen Grab di Kota Kupang agar dapat menigkatkan program insentif bagi para pengemudi sehingga dapat mendorong pengemudi untuk berkinerja baik.
\end{abstract}

Kata Kunci: Insentif, Kinerja

\begin{abstract}
This study aims to determine the effect of incentives on the performance of Grab Bike drivers in Kupang City. This research is an associative research using a quantitative approach. Data collection techniques were carried out by distributing questionnaires, conducting observations and interviews. The data analysis technique used in this research is simple linear regression. This research was conducted on Grab Bike drivers in the city of Kupang with a sample of 83 drivers. The results of data analysis show that incentives have a positive effect on the performance of Grab Bike drivers in the city of Kupang. This finding can be used as evaluation material for Grab management in Kupang City to improve incentive programs for drivers so that they can encourage driver performance well.
\end{abstract}

Keywords: Incentives, Performance.

Naskah diterima : 04-08-2021, Naskah dipublikasikan : 28-09-2021

\section{PENDAHULUAN}

Sumber daya manusia merupakan salah satu faktor penting dalam suatu organisasi atau perusahaan. Agar aktivitas manajemen berjalan dengan baik, perusahaan harus memiliki karyawan yang berpengetahuan dan berketerampilan tinggi serta usaha untuk mengelola perusahaan seoptimal mungkin sehingga dapat meningkatkan kinerja. Sumber daya manusia merupakan salah satu modal utama dalam suatu organisasi, dimana dapat memberikan kontribusi yang tidak ternilai dalam strategi pencapaian tujuan organisasi. Kinerja merupakan bagian yang sangat penting dan menarik karena terbukti sangat penting manfaatnya. Oleh karena itu upayaupaya untuk meningkatkan kinerja karyawan merupakan tantangan manajemen yang paling serius, karena keberhasilan untuk mencapai tujuan dan keberlangsungan hidup perusahaan tergantung pada kualitas kinerja sumberdaya manusia yang ada didalamnya (Syamsuddinnor, 2014 ). 
Kinerja merupakan suatu hasil kerja yang dicapai seseorang dalam melaksanakan tugastugasnya yang dibebankan kepadanya yang didasarkan atas kecakapan, pengalaman dan kesungguhan serta waktu (Hasibuan, 2014). Untuk menciptakan kinerja karyawan dengan kualitas tinggi dapat dipengaruhi juga oleh tindakan perusahaan dalam memenuhi faktor-faktor kebutuhan dan keinginan karyawan. Ada beberapa hal yang harus dipenuhi perusahaan untuk mencapai kinerja karyawan dengan kualitas tinggi termasuk didalamnya yaitu bagaimana untuk menerapkan "Insentif" bagi karyawan-karyawan tersebut. Besar kecilnya insentif yang diperoleh berpengaruh terhadap kinerja karyawan tersebut. Apabila karyawan tidak menerima insentif sesuai dengan besarnya pengorbanan dalam bekerja maka hal itu akan mengurangi semangatnya dalam bekerja.

Pemberian Insentif yang tepat serta cara kerja yang baik dapat meningkatkan kinerja karyawan sehingga kedepannya proses kerja organisasi dapat berjalan sesuai dengan tujuan organisasi. Insentif merupakan perangsang yang ditawarkan kepada para karyawan untuk melaksanakan kerja sesuai atau lebih tinggi dari standar-standar yang telah ditetapkan (Handoko, 2014: 176). Insentif umumnya dilakukan sebagai strategi untuk meningkatkan produktivitas dan efisiensi perusahaan dengan memanfaatkan perilaku pegawai yang mempunyai kecenderungan kemungkinan bekerja seadanya atau tidak optimal. Sehingga dengan adanya pemberian insentif yang diberikan kepada karyawan meningkatkan kinerja karyawan tersebut. Insentif sangat diperlukan untuk memacu kinerja para karyawan agar selalu berada pada tingkat tertinggi atau optimal sesuai kemampuan masing-masing. Peran insentif cukup besar dalam membentuk karyawan potensial. Insentif merupakan salah satu bentuk pemberian gaji, upah dan penghargaan yang diberikan kepada karyawan terkait dengan kontribusi karyawan dalam pencapaian tujuan perusahaan. Pemberian insentif yang tinggi dan relevan akan berpengaruh terhadap kinerja karyawan, hal ini didukung oleh penelitian yang dilakukan oleh Tjitradjaya dan Joanna (dalam Wasisto, 2014) yang menunjukan hasil bahwa insentif dan motivasi sangat berpengaruh dalam kinerja karyawan, sehingga perusahaan ada baiknya memberikan insentif dan motivasi yang sesuai sehingga meningkatkan kinerja karyawan.

Salah satu perusahaan yang menerapkan sistem pemberian Insentif untuk meningkatkan Kinerja karyawan adalah perusahaan transportasi online yakni Grab. Grab merupakan salah satu perusahaan teknologi asal Malaysia yang berkantor di Singapura yang menyediakan aplikasi layanan transportasi umum meliputi kendaraan bermotor roda 2 maupun roda 4. Dengan aplikasi Grab, calon penumpang dapat dengan mudah mencari pengemudi untuk menuju ke lokasi tujuan, sehingga tidak perlu waktu yang lama untuk mendapatkan transportasi yang diperlukan. Grab didirikan pada tahun 2011 di Malaysia, pendirinya adalah Anthony Tan bersama rekannya Tan Hooi. Dari tahun 2011 sampai saat ini, Grab berkembang pesat dan menjadi salah satu penyedia aplikasi transportasi online di Indonesia. Selama ini, Grab telah memiliki fitur layanan diantaranya : Grab Taxi, Grab Car, Grab Bike, Grab Express dan Grab Food. Sistem pemberian Insentif kepada para pengemudi Grab dilakukan apabila pengemudi tersebut sudah mencapai target yang ditetapkan dari perusahaan, dimana target tersebut diukur berdasarkan perolehan poin berupa "Berlian" yang terdapat pada aplikasi yang digunakan oleh setiap pengemudi. Setiap orderan konsumen atau penumpang bernilai 10 poin berlian untuk jenis layanan Grab Bike dan Grab Expres dan 15 poin berlian untuk jenis layanan Grab Food untuk masing-masing orderan. Para pengemudi akan memperoleh Insentif harian apabila telah mencapai target yang ditentukan oleh perusahaan, setiap jenis layanan memiliki target dan insentif yang berbeda-beda dimana untuk layanan Grab Bike para pengemudi harus mengumpulkan berlian sebanyak 100 poin untuk dapat memperoleh insentif sebesar Rp. 14.000, untuk layanan Grab Expres para pengemudi harus mengumpulkan poin sebanyak 150 untuk dapat memperoleh insentif sebesar Rp. 21.000, sedangkan untuk layanan Grab food, para pengemudi harus mengumpulkan 200 poin untuk dapat memperoleh insentif sebesar Rp. 40.000. 
Tabel 1. Perolehan Insentif Grab

\begin{tabular}{|l|l|l|l|l|}
\hline No & \multicolumn{1}{|c|}{ Jenis layanan } & $\begin{array}{c}\text { Jumlah Poin } \\
\text { Berlian }\end{array}$ & $\begin{array}{c}\text { Jumlah } \\
\text { Target }\end{array}$ & \multicolumn{1}{|c|}{$\begin{array}{c}\text { Insentif Yang } \\
\text { diperoleh }\end{array}$} \\
\hline 1. & Grab Bike & 10 Poin & 100 Poin & Rp. 14.000 \\
\hline 2. & Grab Expres & 10 Poin & 150 Poin & Rp. 21.000 \\
\hline 3. & Grab food & 15 Poin & 200 Poin & Rp. 40.000 \\
\hline
\end{tabular}

Sumber: Data Primer yang diolah (2020)

Apabila dalam satu hari para pengemudi dapat memperoleh jumlah berlian sebanyak 240 poin dari ketiga jenis layanan tersebut misalnya grab food sebanyak 200 poin dan grab bike 40 poin, atau 150 poin grab expres dan 90 poin grab bike, maka Insentif yang diterima yaitu Rp.55.000 dari perusahaan. Jika melihat jumlah insentif yang diberikan Grab terhadap para pengemudinya yang memenuhi target dalam sehari maka penulis berasumsi bahwa motivasi kerja para pengemudi Grab didorong oleh target harian dan insentif yang diberikan. Namun, jika dihitung jumlah insentif yang diberikan Grab pada pengemudinya yang memenuhi target harian dalam sebulan maka pendapatan yang diterima penemudi adalah Rp 1.650.000 - Rp 1.705.000 per bulan. Jumlah ini masih berada dibawah Upah Minimum Kota (UMK) Kupang pada tahun 2020 yaitu Rp 2.007.500 sehingga penulis ingin melihat bagaimana pengaruh insentif terhadap kinerja para pengemudi Grab di Kota Kupang sekalipun insentif yang mereka terima masih jauh dari UMK. Berdasarkan pemaparan-pemaparan di atas maka penulis melakukan penelitian dengan judul Pengaruh Insentif Terhadap Kinerja Pengemudi Grab Bike di Kota Kupang. Adapun rumusan masalah untuk penelitian ini adalah Bagaimana pengaruh Insentif terhadap Kinerja Pengemudi Grab Bike di Kota Kupang?

\section{KAJIAN LITERATUR Kinerja}

Kinerja dapat diartikan sebagai prestasi atau efektivitas operasional suatu organisasi dan karyawan yang didasarkan pada sasaran standart dan kriteria yang telah ditetapkan sebelumnya. Moeheriono (2012) menjelaskan bahwa kinerja adalah hasil kerja yang dicapai oleh seseorang atau kelompok orang dalam suatu organisasi baik secara kuantitatif, sesuai dengan kewenangan dan tugas tanggung jawab masing-masing, dalam upaya mencapai tujuan organisasi yang bersangkutan secara legal, tidak melanggar hukum dan sesuai dengan moral atau etika. Kinerja (performance) mengacu kepada kadar pencapaian tugas-tugas yang membentuk sebuah pekerjaan karyawan. Kinerja merefleksikan seberapa baik karyawan memenuhi persyaratan sebuah pekerjaan (Simamora, 2015). Dengan demikian, kinerja merupakan hasil dan perilaku kerja yang ditunjukan oleh seorang karyawan sesuai dengan perannya dalam organisasi selama suatu periode waktu tertentu. Kinerja diukur dengan penilaian kinerja. Penilaian kinerja adalah proses evaluasi terhadap karyawan dalam melakukan pekerjaan yang dikomparasikan dengan standar, yang dilanjutkan dengan memberi informasi tersebut kepada karyawan. Penilaian kinerja sering disebut juga pemberian peringkat pada karyawan melalui peninjauan, evaluasi dan penilaian hasil kerja (Mathis dan Jackson, 2016: 382). Adapun penilaian kinerja adalah aktivitas bagi para manajer untuk melakukan evaluasi terhadap tingkah laku berprestasi para karyawan yang dilanjutkan dengan menentukan kebijaksanaan kedepannya. Hal yang berkaitan dengan penilaian kinerja seperti penilaian loyalitas, kejujuran, leadership, teamwork, dedikasi, dan partisipasi (Hasibuan, 2014: 87).

Kinerja dipengaruhi oleh beragam faktor. Menurut Gibson (dalam Awallunnisa dan Agustin, 2015), ada tiga faktor yang berpengaruh terhadap kinerja yakni:

1. Faktor Individu: kemampuan, keterampilan, latar belakang keluarga, pengalaman kerja, tingkat sosial dan demografi seseorang.

2. Faktor Psikologis: presepsi, peran, sikap, kepribadian, motivasi dan kepuasan kerja. 
3. Faktor Organisasi: struktur organisasi, desain pekerjaaan, kepemimpinan, sistem penghargaan.

Sedangkan menurut Robbins (2013: 206), terdapat enam indikator untuk mengukur kinerja karyawan, yaitu:

1. Kualitas

Kualitas kerja diukur dari persepsi karyawan terhadap kualitas pekerjaan yang dihasilkan serta kesempurnaan tugas terhadap keterampilan dan kemampuan karyawan.

2. Kuantitas

Kuantitas merupakan jumlah yang dihasilkan dinyatakan dalam istilah seperti jumlah unit, jumlah siklus aktivitas yang diselesaikan.

3. Ketepatan waktu

Ketepatan waktu merupakan tingkat aktivitas diselesaikan pada awal waktu yang dinyatakan, dilihat dari sudut koordinasi dengan hasil output serta memaksimalkan waktu yang tersedia untuk aktivitas lain.

4. Efektivitas

Efektivitas merupakan tingkat penggunaan sumber daya organisasi (tenaga, uang teknologi, bahan baku) dimaksimalkan dengan maksud menaikkan hasil setiap unit dalam penggunaan sumber daya.

5. Kemandirian

Kemandirian merupakan tingkat seorang karyawan yang nantinya akan dapat menjalankan fungsi kerjanya

6. Komitmen Kerja

Komitmen kerja merupakan suatu tingkat dimana karyawan memiliki komitmen kerja dengan instansi dan tanggung jawab karyawan terhadap kantor.

\section{Insentif}

Menurut Dessler (2015), insentif adalah peningkatan gaji yang dihadiahkan kepada seorang karyawan pada suatu waktu yang ditentukan dalam bentuk gaji pokok yang lebih tinggi, biasanya didasarkan secara eksklusif pada kinerja individual. Insentif umumnya dilakukan sebagai strategi untuk meningkatkan produktivitas dan efisiensi perusahaan dengan memanfaatkan perilaku pegawai yang mempunyai kecenderungan kemungkinan bekerja seadanya atau tidak optimal. Dengan demikian, dapat disimpulkan bahwa insentif diberikan secara sengaja kepada karyawan agar tercipta suatu dorongan untuk meningkatkan prestasi kerja sehingga menimbulkan dampak baik bagi perusahaan denganadanya kinerja yang baik dan berkualitas dari seorang karyawan.

Menurut Gorda (2012: 156) pemberian Insentif atau upah perangsang bertujuan :

1. Memberikan balas jasa yang berbeda dikarenakan hasil kerja yang berbeda.

2. Mendorong semangat kerja karyawan dan memberikan kepuasan.

3. Meningkatkan produktivitas

4. Dalam melakukan tugasnya, seorang pemimpin selalu membutuhkan bawahannya untuk melaksanakan rencana-rencananya.

5. Pemberian Insentif dimaksudkan untuk menambah penghasilan karyawan sehingga dapat memenuhi kebutuhannya.

6. Mempertahankan karyawan yang berprestasi agar tetap berada dalam perusahaan.

Menurut Siagian (2012) jenis-jenis Insentif adalah sebagai berikut:

1. Piecework

Piecework merupakan insentif yang diberikan berdasarkan jumlah output atau barang yang di hasilkan pekerja. Sistem ini bersifat individual standarnya output perunit 
digunakan untuk pekerja yang outputnya sangat jelas dan dapat di ukur dengan mudah dalam organisasi.

2. Bonus

Bonus merupakan tambahan upah yang diterima karena hasil kerja yang melebihi standar yang di tentukan dimana karyawan juga mendapatkan upah pokok.

3. Komisi

Komisi merupakan insentif diberikan berdasarkan jumlah barang yang terjual, sistem ini biasanya digunakan tenaga penjual. Standar sistem ini adalah penjualan yang dapat di ukur dengan jelas.

4. Insentif Eksekutif

Adalah jenis insentif yang diberikan kepada pegawai setingkat manajer atau pegawai yang berkedudukan tinggi dalam perusahaan.

5. Kurva Kematangan

Yaitu insentif yang diberikan kepada karyawan atau tenaga kerja, dikarenakan masa kerja dan golongan pangkat serta gaji sudah tidak dapat mencapai pangkat dan penghasilan yang lebih tinggi lagi.

Jenis insentif yang berlaku dalam Grab adalah insentif material berupa bonus harian dan insentif non-material berupa pemberian pujian kepada para pengemudi oleh para konsumen atau pengguna baik secara langsung maupun tidak langsung yaitu melalui aplikasi yang digunakan.

Menurut Sirait ( 2012: 202 ), Indikator Insentif adalah sebagai berikut :

1. Financial Incetive

Insentif yang diberikan kepada tenaga kerja atas prestasinya dalam organisasi atau perusahaan dalam bentuk bonus, komisi, pembayaran yang ditangguhkan.

2. Non-financial Incentive

Insentif diberikan kepada tenaga kerja bukan dalam bentuk uang atau barang, tetapi dalam bentuk hiburan, pendidikan dan latihan, penghargaan berupa pujian serta tempatg kerja yang terjamin, sehingga diharapkan dapat memotivasi pekerja agar semakin giat.

3. Sosial Incentive

Keadaan dan sikap rekan kerja merupakan salah satu pendukung untuk meningkatkan produktivitas tenaga kerja.

Umumnya perusahaan menyakini bahwa pemberian imbalan dan insentif mempengaruhi kinerja karyawan. Salah satu alasan penting pembayaran insentif karena adanya ketidaksesuaian tingkat kompensasi yang dibayarkan kepada eksekutif dengan pekerjaan lain. Program insentif adalah suatu cara untuk meningkatkan seluruh pekerja merasakan bersama kemakmuran perusahaan. Selain itu adanya kesadaran yang timbul bahwa progam pembayaran tradisional seringkali tidak bagus dalam menghubungkan pembayaran dengan kinerja. pembayaran perlu dihubungkan dengan kinerja sedemikian rupa sehingga pembayaran itu mengikuti tujuan karyawan dan tujuan organisasi yang terdiri dari bonus tahunan, insentif langsung, insentif tidak langsung, insentif individu, insentif kelompok, pembagian keuntungan, bagi hasil (Rivai 2015 : 769).

\section{Hubungan Insentif dan Kinerja}

Pandangan Wibowo (2012) menyebutkan bahwa Insentif mempunyai hubungan dengan kinerja karyawan, karena setiap pekerja yang telah memberikan kinerja terbaiknya pasti mengharapkan imbalan disamping gaji atau upah sebagai tambahan berupa insentif atas prestasi yang telah diberikannya terhadap perusahaan. Dengan demikian, apabila organisasi dapat memberikannya, akan meningkatkan motivasi, partisipasi dan membangun saling pengertian dan saling percaya pekerja dan atasan. Insentif materil dan insentif non-materil berpengaruh positif dan signifikan terhadap kinerja karyawan. Handoko (2014) istilah sistem insentif pada umumnya digunakan untuk menggambarkan rencana-rencana pembayaran upah yang dikaitkan secara 
langsung atau tidak langsung dengan berbagai standar produktivitas atau kinerja karyawan atau profitabilitas organisasi atau kedua kriteria tersebut. Oleh karena itu, para karyawan yang bekerja dibawah sistem insentif berarti prestasi kerja mereka menentukan secara keseluruhan atau sebagian penghasilan mereka.

\section{Kerangka Pemikiran}

Kinerja merupakan hasil dan perilaku kerja yang ditunjukan oleh seorang karyawan sesuai dengan perannya dalam organisasi selama satu periode waktu tertentu. Dalam penelitian ini, kinerja pengemudi grab bike diukur berdasarkan kualitas kerja, kuantitas kerja, ketepatan waktu, efektifitas, kemandirian, dan komitmen kerja pengemudi dalam bekerja berdasarkan teori yang dikemukakan oleh Robbins (2013: 206). Insentif merupakan perangsang atau tambahan balas jasa kepada karyawan yang ditawarkan untuk melaksanakan pekerjaan sesuai atau lebih tinggi dari yang ditetapkan. Insentif yang diperoleh pengemudi grab dikota kupang berupa insentif material dalam bentuk bonus dan insentif non material dalam bentuk pujian dan ucapan terima kasih, sesuai dengan indikator insentif menurut Sarwoto (2012: 156). Dalam penelitian ini peneliti hanya menggunakan indikator materill berupa bonus, karena menyesuaikan dengan objek dalam penelitian ini, dimana para pengemudi Grab Bike hanya mendapat bonus sebagai insentif materill dari perusahaan.

Kerangka pemikiran diatas dapat digambarkan dalam skema hubungan antar variabel sebagai berikut :

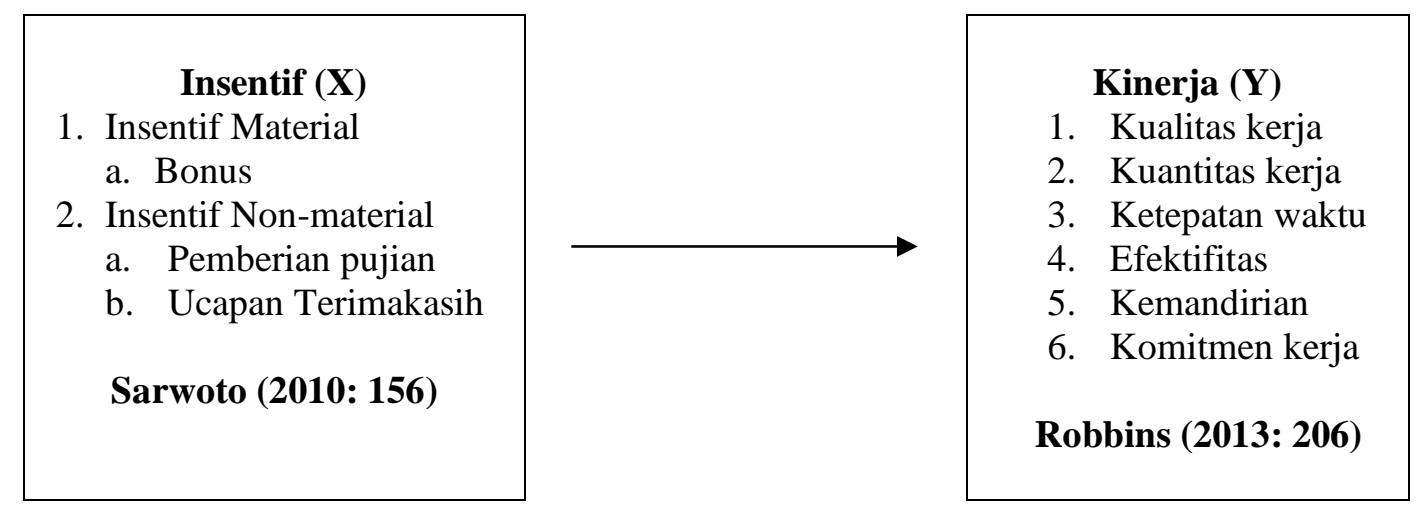

Gambar 1. Kerangka Berpikir

Hipotesis pada penelitian ini dirumuskan sebagai berikut: "Diduga Insentif berpengaruh positif secara signifikan terhadap kinerja pengemudi Grab di Kota Kupang".

\section{METODE PENELITIAN}

Penelitian ini merupakan penelitian asosiatif dengan menggunakan dengan menggunakan pendekatan kuantitatif. Alat analisis yang digunakan adalah analisis statistik inferensial. Populasi dalam penelitian ini adalah para pengemudi grab bike sebanyak 500 orang pada Grab di Kota Kupang. Dalam penelitian ini, pengambilan sampel disesuaikan dengan rumus Slovin (Umar, 2014).

Keterangan :

$$
\text { Sampel }(\mathrm{n})=\frac{N}{N(\mathrm{~d})^{2}+1}
$$

$\mathrm{n}=$ Jumlah sampel

$\mathrm{N}=$ Jumlah populasi

d $=$ Standar Error 
Populasi dalam penelitian ini adalah para pengemudi grab bike Kota Kupang berjumlah 500 pengemudi, maka ukuran sampelnya adalah:

$$
\begin{aligned}
& \mathrm{n}=\frac{N}{N(\mathrm{~d})^{2}+1} \\
& \mathrm{n}=\frac{500}{500(0,1)^{2}+1} \\
& \mathrm{n}=\frac{500}{6} \\
& \mathrm{n}=83,33 \text {, dibulatkan menjadi } 83 .
\end{aligned}
$$

Teknik pengambilan sampel yang digunakan dalam penelitian ini adalah probability sampling, yaitu simple random sampling dimana pengambilan sampel populasi dilakukan secara acak tanpa memperhatikan strata yang ada dalam populasi itu. ini yaitu:

Penelitian ini menggunakan data kuantitatif dan kualitatif. Sumber data dalam penelitian

1. Data Primer, yaitu data dari hasil dari observasi, wawancara, dan kuesioner yang dibagikan kepada pengemudi Grab Kota Kupang.

2. Data sekunder, yaitu hasil studi pustaka, literatur, penelitian terdahulu, buku dan data karyawan, besaran gaji, masa kerja pengemudi Grab Kota Kupang.

Intrumen penelitian yang digunakan diuji dengan Uji Validitas dan Uji Reabilitas. Uji validitas bertujuan untuk menguji apakah tiap-tiap butir pertanyaan benar-benar telah mengungkapkan faktor atau indikator yang ingin diteliti. Instrumen dikatakan valid berarti menunjukkan alat ukur yang digunakan untuk mendapatkan data itu valid atau dapat digunakan untuk mengukur apa yang seharusnya diukur (Sugiyono, 2014:117). Adapun hasil uji validitas terhadap semua item pertanyaan baik pada variabel insentif (X) dan kinerja (Y) tersaji pada tabel berikut:

Tabel 2. Hasil Uji Validitas

\begin{tabular}{|c|c|c|c|c|}
\hline Variabel & No. Item Pertanyaan & r Hitung & r Tabel & Keterangan \\
\hline Insentif (X) & Item 1 & $0,557^{* *}$ & 0,181 & Valid \\
\cline { 2 - 5 } & Item 2 & $0,656^{* *}$ & 0,181 & Valid \\
\cline { 2 - 5 } & Item 3 & $0,629^{* *}$ & 0,181 & Valid \\
\cline { 2 - 5 } & Item 4 & $0,726^{* *}$ & 0,181 & Valid \\
\cline { 2 - 5 } & Item 5 & $0,494^{* *}$ & 0,181 & Valid \\
\cline { 2 - 5 } & Item 6 & $0,651^{* *}$ & 0,181 & Valid \\
\cline { 2 - 5 } & Item 7 & $0,629^{* *}$ & 0,181 & Valid \\
\cline { 2 - 5 } & Item 8 & $0,542^{* *}$ & 0,181 & Valid \\
\cline { 2 - 5 } & Item 9 & $0,619^{* *}$ & 0,181 & Valid \\
\cline { 2 - 5 } & Item 10 & $0,636^{* *}$ & 0,181 & Valid \\
\cline { 2 - 5 } & Item 11 & $0,642^{* *}$ & 0,181 & Valid \\
\hline Kinerja (Y) & Item 12 & $0,589^{* *}$ & 0,181 & Valid \\
\cline { 2 - 5 } & Item 13 & $0,556^{* *}$ & 0,181 & Valid \\
\cline { 2 - 5 } & Item 14 & $0,488^{* *}$ & 0,181 & Valid \\
\cline { 2 - 5 } & Item 15 & $0,508^{* *}$ & 0,181 & Valid \\
\cline { 2 - 5 } & Item 16 & $0,659^{* *}$ & 0,181 & Valid \\
\cline { 2 - 5 } & Item 17 & $0,388^{* *}$ & 0,181 & Valid \\
\cline { 2 - 5 } & Item 18 & $0,488^{* *}$ & 0,181 & Valid \\
\cline { 2 - 5 } & Item 19 & $0,556^{* *}$ & 0,181 & Valid \\
\cline { 2 - 5 } & Item 20 & $0,011 * *$ & 0,181 & Tidak Valid \\
\cline { 2 - 5 } & Item 21 & $0,304 * *$ & 0,181 & Valid \\
\hline
\end{tabular}




\begin{tabular}{|c|c|c|c|c|}
\hline Variabel & No. Item Pertanyaan & r Hitung & r Tabel & Keterangan \\
\hline \multirow{6}{*}{} & Item 22 & $0,044 * *$ & 0,181 & Tidak Valid \\
\cline { 2 - 5 } & Item 23 & $0,381 * *$ & 0,181 & Valid \\
\cline { 2 - 5 } & Item 24 & $0,523 * *$ & 0,181 & Valid \\
\cline { 2 - 5 } & Item 25 & $0,348 * *$ & 0,181 & Valid \\
\cline { 2 - 5 } & Item 26 & $0,559 * *$ & 0,181 & Valid \\
\cline { 2 - 5 } & Item 27 & $0,267 * *$ & 0,181 & Valid \\
\cline { 2 - 5 } & Item 28 & $0,436 * *$ & 0,181 & Valid \\
\hline
\end{tabular}

Sumber: Data Primer (2020)

Dari hasil data variabel insentif dan kinerja diatas dengan nilai $r$ tabel sebesar 0.181 dan untuk nilai $r$ hitung dengan nilai pada item pertanyaan pertama sebesar 0,557 yang artinya $r$ hitung lebih besar dari $r$ tabel $(0,557>0.181)$ sehingga dikatakan valid untuk penelitian selanjutnya dapat digunakan untuk analisis selanjutnya. Sedangkan pada item pertanyaan nomor 20 dan 22 butir pertanyaannya tidak valid sehingga akan disaring dan tersisa butir-butir pertanyaan yang lolos uji validitas. Sedangkan, Uji reliabilitas bertujuan untuk menguji apakah kuesioner yang dibagikan kepada responden benar-benar dapat diandalkan sebagai alat pengukur. Alat instrument di evaluasi dengan melihat analisis reliability menggunakan Alpha Cronbach yang juga dapat digunakan untuk mengukur validitas. Berikut hasil uji reliabilitas :

Tabel 3. Uji Reliabilitas

\begin{tabular}{|c|c|c|c|c|}
\hline No. & Variabel & Hasil Uji & Kriteria & Keterangan \\
\hline 1 & Insentif & 0,847 & $\geq 0,60$ & Reliabel \\
\hline 2 & Kinerja & 0,709 & $\geq 0,60$ & Reliabel \\
\hline
\end{tabular}

Sumber: Data Primer (2020)

Hasil uji reliabilitas menunjukkan nilai cronbach's alpha Variabel Insentif sebesar 0,847 dan Variabel Kinerja sebesar 0,709 atau lebih besar dari nilai minimal cronbach's alpha sebesar 0,60 sehingga dapat disimpulkan bahwa instrumen penelitian dalam penelitian ini dinyatakan reliabel. Data yang diperoleh kemudia dianalisis dengan dua teknik yaitu analisis deskriptif dan analisis inferensial. Menurut Ghozali (2012), statistik deskriptif adalah statistik yang memberikan gambaran atau deskripsi suatu data yang dilihat dari nilai rata-rata (mean), standar deviasi, varian, maksimum, sum, range, kurtosis, dan skewness (kemengcengan distribusi). Skala yang digunakan dalam penelitian ini adalah skala likert. Dalam menganalisis variabel, semua variabel diukur dengan instrmen pengukuran dalam bentuk kuesioner yang didalamnya terdapat pertanyaan dengan alternatif jawaban. Setelah memperoleh data kuesioner,dilakukan perhitungan statistik maka dapat diketahui bobot nilai dari setiap item-item pertanyaan. Selain itu, jawaban dari responden dapat dihitung untuk mengetahui hubungan antar variabel yang diteliti, dan selanjutnya disajikan dalam bentuk tabel untuk dihitung rata-rata tersebut untuk diinterprestasikan dalam kategori kriteria penilaian (Sugiyono, 2013).

$$
\text { NJI ( Nilai Jenjang Interval })=\frac{\text { Nilai maksimun }- \text { Nilai minimum }}{J u m l a h ~ K e l a s ~}
$$

Untuk melihat tanggapan responden terhadap indikator-indikator dan juga rata-rata skor untuk variable insentif dan kinerja dapat diuraikan sebagai berikut :

Klasifikasi skor item Variabel X dan Y

Skor minimum $=1 \mathrm{x}$ jumlah responden $=1 \times 83=83$

Skor maksimum $=5 \mathrm{x}$ jumlah responden $=5 \mathrm{x} 83=415$

$$
R=\frac{\text { skor maksimal }- \text { skor minimum }}{J K}=\frac{415-83}{5}=66,4
$$


Berdasarkan skor maksimum dan minimum serta rentang skor tersebut maka klasifikasi skor untuk item secara keseluruhan:

Tabel 4. Kriteria Penilaian Skor Item Variabel X dan Y

\begin{tabular}{|c|c|}
\hline Rentang Skor & Kriteria Penilaian \\
\hline $83-149,4$ & Sangat rendah \\
\hline $149,5-215,8$ & Rendah \\
\hline $215,9-282,2$ & Sedang \\
\hline $282,3-348,6$ & Tinggi \\
\hline $348,7-415$ & Sangat Tinggi \\
\hline
\end{tabular}

Sumber: Data Primer (2020)

Klasifikasi Skor Indikator

Untuk Indikator Dengan 1 Item pertanyaan

Skor minimum $=1 \times$ jumlah responden $=1 \times 83 \times 1=83$

Skor maksimum $=5 \mathrm{x}$ jumlah responden $=5 \times 83 \times 1=415$

$$
R=\frac{\text { skor maksimal }- \text { skor minimum }}{J K}=\frac{415-83}{5}=66,4
$$

Untuk Indikator Dengan 2 Item pertanyaan

Skor minimum $=1 \times$ jumlah responden $=1 \times 83 \times 2=166$

Skor maksimum $=5 \mathrm{x}$ jumlah responden $=5 \mathrm{x} 83 \times 2=830$

$$
R=\frac{\text { skor maksimal }- \text { skor minimum }}{J K}=\frac{830-166}{5}=132,8
$$

Untuk Indikator Dengan 3 Item pertanyaan

Skor minimum $=1 \times$ jumlah responden $=1 \times 83 \times 3=249$

Skor maksimum $=5 \mathrm{x}$ jumlah responden $=5 \times 83 \times 3=1245$

$$
R=\frac{\text { skor maksimal }- \text { skor minimum }}{J K}=\frac{1245-249}{5}=199,2
$$

Untuk Indikator Dengan 4 Item pernyataan

Skor minimum $=1 \times$ jumlah responden $=1 \times 83 \times 4=332$

Skor maksimum $=5 \times$ jumlah responden $=5 \times 83 \times 4=1660$

$$
R=\frac{\text { skor maksimal }- \text { skor minimum }}{J K}=\frac{1660-332}{5}=265,6
$$

Untuk Indikator Dengan 5 Item pertanyaan

Skor minimum $=1 \times$ jumlah responden $=1 \times 83 \times 5=415$

Skormaksimum $=5 \mathrm{x}$ jumlah responden $=5 \mathrm{x} 85 \mathrm{x} 5=2075$

$$
R=\frac{\text { skor maksimal }- \text { skor minimum }}{J K}=\frac{2075-415}{5}=332
$$

Untuk Indikator Dengan 7 Item pertanyaan

Skor minimum $=1 \times$ jumlah responden $=1 \times 83 \times 7=581$

Skormaksimum $=5 \times$ jumlah responden $=5 \times 85 \times 7=2905$

$$
R=\frac{\text { skor maksimal }- \text { skor minimum }}{J K}=\frac{2905-581}{5}=464,8
$$


Tabel 5. Kriteria Penilaian Skor Indikator X dan Y

\begin{tabular}{|c|c|c|c|c|}
\hline \multicolumn{4}{|c|}{ Rentang Skor } & Kriteria Penilaian \\
\hline 2 Item & 3 Item & 4 Item & Item 5 & \\
\hline $166-298,8$ & $249-448,2$ & $332-597,6$ & $415-747$ & Sangat Rendah \\
\hline $298,9-431,6$ & $448,3-647,4$ & $597,7-863,2$ & $748-1079$ & Rendah \\
\hline $431,7-564,4$ & $647,5-846,6$ & $863,3-1128,8$ & $1078-1411$ & Sedang \\
\hline $564,5-697,2$ & $846,7-1045,8$ & $1128,9-1394,4$ & $1412-1743$ & Tinggi \\
\hline $697,3-830$ & $1045,9-1245$ & $1394,5-1660$ & $1744-2075$ & Sangat Tinggi \\
\hline
\end{tabular}

Sumber: Data Primer (2020)

Klasifikasi Skor Variabel

Untuk Variabel Insentif (X)

Skor minimum $=1 \times$ jumlah responden $=1 \times 83 \times 12=996$

Skor maksimum $=5 \times$ jumlah responden $=5 \times 83 \times 12=4980$

$$
R=\frac{\text { skor maksimal }- \text { skor minimum }}{J K}=\frac{4980-996}{5}=796,8
$$

Tabel 6. Kriteria penilaian skor variable Insentif (X)

\begin{tabular}{|l|l|}
\hline \multicolumn{1}{|c|}{ Rentang Skor } & \multicolumn{1}{c|}{ Kriteria Penilaian } \\
\hline $996-1792,8$ & Sangat Rendah \\
\hline $1792,9-2589,6$ & Rendah \\
\hline $2589,7-3386,4$ & Sedang \\
\hline $3386,5-4183,2$ & Tinggi \\
\hline $4183,3-4980$ & Sangat Tinggi \\
\hline
\end{tabular}

Sumber : Data Primer (2020)

Untuk Variabel Kinerja (Y)

Skor minimum $=1 \times$ jumlah responden $=1 \times 83 \times 14=1162$

Skor maksimum $=5 \times$ jumlah responden $=5 \times 56 \times 14=5810$

$$
R=\frac{\text { skor maksimal }- \text { skor minimum }}{J K}=\frac{5810-1162}{5}=929,6
$$

Tabel 7. Kriteria Penilaian Skor Variabel Kinerja (Y)

\begin{tabular}{|c|c|}
\hline Rentang Skor & Kriteria penilaian \\
\hline $1162-2091,6$ & Sangat Rendah \\
\hline $2091,7-3021,2$ & Rendah \\
\hline $3021,3-3950,8$ & Sedang \\
\hline $3950,9-4880,4$ & Tinggi \\
\hline $4880,5-5810$ & SangatTinggi \\
\hline
\end{tabular}

Sumber : Data Primer (2020)

Sedangkan, menurut Sugiyono (2012: 207) Analisis Inferensial yaitu teknik statistik yang digunakan untuk menganalisis data sampel dan hasilnya diberlakukan untuk populasi yang jelas dan teknik pengambilan sampel dari populasi dilakukan secara random. Analisis yang digunakan regresi linear sederhana, uji hipotesi (uji t) dan koefisien determinasi $\left(\mathrm{R}^{2}\right)$. 
Analisis regresi linear sederhana digunakan untuk mengetahui hubungan satu variabel independen $(\mathrm{X})$ terhadap satu variabel dependen $(\mathrm{Y})$. Rumus yang digunakan dalam penelitian ini yaitu :

$$
\begin{aligned}
& \text { Dimana : } \\
& \text { Y }=\text { kinerja karyawan } \\
& X=\text { insentif } \\
& \mathrm{a}=\text { konstanta } \\
& \mathrm{b}=\text { koefisien regresi }
\end{aligned}
$$$$
\mathbf{Y}=\mathbf{a}+\mathbf{b} \mathbf{X}
$$

Uji statistik $\mathrm{t}$ digunakan untuk menguji signifikansi variasi hubungan antara variabel $\mathrm{X}$ dan Y (Ghozali, 2012). Hipotesis yang digunakan yaitu:

Ho : $\beta=0$, Insentif secara parsial tidak berpengaruh signifikan terhadap kinerja pengemudi grab bike di kota Kupang.

Ha : $\beta \neq 0$, insentif secara parsial berpengaruh signifikan terhadap kinerja pengemudi grab bike di kota Kupang.

Nilai koefisien Determinasi $\left(\mathrm{R}^{2}\right)$ menunjukkan presentase pengaruh semua variabel independen terhadap variabel dependen. Jika $\mathrm{R}^{2}$ semakin mendekati nol berarti kemampuan variabel insentif dalam menjelaskan variasi pada variabel kinerja semakin lemah. Jika nilai $\mathrm{R}^{2}$ semakin mendekati satu berarti kemampuan variabel insentif dalam menjelaskan variasi pada variabel kinerja semakin kuat.

\section{HASIL DAN PEMBAHASAN \\ Sejarah Perkembangan Grab}

Grab berdiri sejak tahun 2011, didirikan oleh Anthony Tan dan Hooi Ling Tan yang merupakan warga negara malaysia, mereka melihat dampak negatif dari tidak efisiennya sistem transportasi yang ada pada saat itu. Grab merupakan aplikasi layanan transportasi terpopuler di Asia Tenggara yang kini telah berada di Singapura, Indonesia, Filipina, Malaysia, Thailand, dan Vietnam, menghubungkan lebih dari 10 juta penumpang dan 185.000 pengemudi diseluruh wilayah Asia Tenggara. Layanan Grab ditujukan untuk memberikan alternatif berkendara bagi para pengemudi dan penumpang yang menekankan pada kecepatan, keselamatan, dan kepastian. Grab sendiri telah hadir di Indonesia pada bulan juni 2012 sebagai aplikasi pemesanan taksi dan saat itu telah memberikan beragam pilihan transportasi seperti mobil dan ojek.

Layanan Grab yang ditawarkan terdiri atas:

1. Grab taxi, yaitu layanan yang memberikan akses serta kemudahan penumpang menemukan pengemudi taxi terdekat dengan aman.

2. Grab car, yaitu layanan penyewaan mobil pribadi dengan supir yang menghadirkan kebebasan pilihan berkendara yang nyaman dan gaya.

3. Grab bike, yaitu layanan untuk melintasi kemacetan dengan aman dan cepat.

4. Grab food, yaitu layanan pesan antar makanan yang memiliki banyak daftar restoran yang tersedia.

5. Grab express, yaitu layanan kurir express berbasis aplikasi yang menjanjikan kecepatan, kepastian, dan yang paling utama adalah keamanan.

6. Grab hitch, yaitu layanan tebengan separuh harga. Bertemu teman baru sekaligus mengurangi kemacetan.

Perkembangan Grab di kota Kupang sendiri ada sejak bulan Maret tahun 2018, dan menjadi salah satu alternatif yang banyak digemari karena harganya yang lebih murah dan transparan dibandingan ojek dan taksi-taksi konvensional lainnya, selain itu juga Grab menjadi salah satu transportasi online pertama yang ada di kota Kupang, dengan jumlah mitra grab bike 
sebanyak \pm 500 orang dan jenis layanan yang beragam seperti Grab Taxi, Grab Car, Grab Bike, Grab Express, dan Grab Food, menjadikan Grab sebagai alternatif yang sering dipilih oleh masyarakat. Berikut merupakan alamat lengkap dan jam operasional kantor cabang grab di Kupang.

Tabel 8. Alamat dan Jam Operasional Kantor Cabang Grab Kupang

\begin{tabular}{|c|c|c|}
\hline Alamat & Jam Operasional & Contact Person \\
\hline Kompleks Ruko & Seninn-Jumat & Djems (+62 822-3638- \\
Hyperstore, JL. Cak & Jam: 08.00-16.00 WITA & $9088)$ \\
Doko Blok 54/B4 - & \\
Kupang & & \\
\hline
\end{tabular}

\section{Karakteristik Responden}

Tabel 9. Jenis Kelamin

\begin{tabular}{|c|c|c|c|}
\hline No. & Karakteristik Responden & Jumlah Responden & Persentase \\
\hline & Jenis Kelamin & $\mathbf{8 3}$ & $\mathbf{1 0 0 \%}$ \\
\hline 1 & Laki-laki & 61 & $73,5 \%$ \\
\hline 2 & Perempuan & 22 & $26,5 \%$ \\
\hline
\end{tabular}

Hasil penelitian ini menunjukan bahwa mayoritas yang menjadi mitra pengemudi grab bike berjenis kelamin laki-laki. Artinya sebagian besar responden dalam penelitian ini adalah berjenis kelamin laki-laki, karena pada umumnya pekerjaan sebagai pengemudi adalah pekerjaaan laki-laki, dimana mereka tidak gengsi dan lebih aman untuk selalu berada ditempat umum, selain itu juga perempuan yang bekerja sebagai pengemudi grab bike belum begitu umum di kota Kupang.

Tabel 10. Usia

\begin{tabular}{|c|c|c|c|}
\hline No & Usia & $\mathbf{8 3}$ & $\mathbf{1 0 0 \%}$ \\
\hline 1 & $18-36$ & 74 & $89,1 \%$ \\
\hline 2 & $37-54$ & 9 & $10,9 \%$ \\
\hline
\end{tabular}

Tabel 10 menunjukkan bahwa disimpulkan sebagian besar pengemudi yang bekerja berusia produktif yaitu usia 18-36 tahun, dimana seseorang bekerja dengan giat dan berani mengambil keputusan secara tegas dan tidak main-main, selain itu pada usia ini mulai timbul keinginan untuk memenuhi kebutuhan mereka, namun mereka belum memiliki pekerjaan tetap sehingga menjadi pengemudi grab bike menjadi salah satu alternatif yang dipilih karena mereka tidak harus mengeluarkan modal yang besar untuk mendapatkan penghasilan setiap hari.

Tabel 11. Pendidikan Terakhir

\begin{tabular}{|c|c|c|c|}
\hline \multicolumn{2}{|c|}{ Pendidikan Terakhir } & $\mathbf{8 3}$ & $\mathbf{1 0 0 \%}$ \\
\hline 1 & SMA/SMK & 45 & $54,2 \%$ \\
\hline 2 & Diploma & 8 & $9,7 \%$ \\
\hline 3 & Sarjana & 30 & $36,1 \%$ \\
\hline
\end{tabular}

Tabel 11 menunjukkan bahwa mayoritas responden dalam penelitian ini berpendidikan SMA/SMK yaitu dengan presentase $54.2 \%$. Hal ini menunjukan bahwa pada usia ini seseorang mulai memiliki keinginan bekerja untuk memenuhi kebutuhannya sendiri, Hal sejalan dengan pendapat Hidayat (2014), yakni umur mempengaruhi tingkat partisipasi kerja. Masyarakat yang berumur muda umumnya mempunyai tanggung jawab yang tidak begitu besar sebagai pencari nafkah untuk keluarga, bahkan umumnya mereka bersekolah, sama halnya dengan objek dalam penelitian ini, dimana rata-rata pengemudi grab bike yang berusia muda memilih bekerja sebagai grab bike hanya untuk memenuhi kebutuhan dan keinginannya sendiri. 


\section{Deskripsi Variabel Penelitian}

Tabel 12. Deskripsi Data Variabel Insentif (X)

\begin{tabular}{|c|c|c|c|c|c|c|c|c|}
\hline \multirow[t]{2}{*}{ No } & \multirow[t]{2}{*}{ Indikator /Item } & \multicolumn{5}{|c|}{ Skors } & \multirow[b]{2}{*}{ Jumlah } & \multirow{2}{*}{$\begin{array}{c}\text { Kriteria } \\
\text { Penilaian }\end{array}$} \\
\hline & & 5 & 4 & 3 & 2 & 1 & & \\
\hline \multicolumn{7}{|c|}{ Bonus } & 1887 & $\begin{array}{l}\text { Sangat } \\
\text { Tinggi }\end{array}$ \\
\hline 1 & $\begin{array}{l}\text { Perusahaan memberi bonus jika saya } \\
\text { mampu memenuhi target yang ditentukan. }\end{array}$ & 55 & 27 & 1 & 0 & 0 & 386 & $\begin{array}{l}\text { Sangat } \\
\text { Tinggi }\end{array}$ \\
\hline 2 & $\begin{array}{l}\text { Bonus yang saya terima dari perusahaan } \\
\text { memuaskan. }\end{array}$ & 56 & 24 & 3 & 0 & 0 & 385 & $\begin{array}{l}\text { Sangat } \\
\text { Tinggi }\end{array}$ \\
\hline 3 & $\begin{array}{l}\text { Bonus yang diberikan perusahaan cukup } \\
\text { adil. }\end{array}$ & 49 & 31 & 1 & 0 & 0 & 372 & $\begin{array}{l}\text { Sangat } \\
\text { Tinggi }\end{array}$ \\
\hline 4 & $\begin{array}{l}\text { Dengan adanya bonus dari perusahaan, } \\
\text { membuat saya lebih semangat bekerja }\end{array}$ & 44 & 35 & 3 & 1 & 0 & 369 & $\begin{array}{l}\text { Sangat } \\
\text { Tinggi }\end{array}$ \\
\hline 5 & Bonus selalu diterima tepat waktu. & 50 & 26 & 7 & 0 & 0 & 375 & $\begin{array}{l}\text { Sangat } \\
\text { Tinggi }\end{array}$ \\
\hline \multicolumn{7}{|c|}{ Pujian } & 1474 & $\begin{array}{l}\text { Sangat } \\
\text { Tinggi }\end{array}$ \\
\hline 6 & $\begin{array}{l}\text { Perusahaan selalu memberikan pujian } \\
\text { ketika saya mampu mencapai target yang } \\
\text { ditetapkan. }\end{array}$ & 45 & 30 & 7 & 1 & 0 & 366 & $\begin{array}{l}\text { Sangat } \\
\text { Tinggi }\end{array}$ \\
\hline 7 & $\begin{array}{l}\text { Pujian membuat saya lebih bersemangat } \\
\text { dalam bekerja. }\end{array}$ & 44 & 32 & 7 & 0 & 0 & 369 & $\begin{array}{l}\text { Sangat } \\
\text { Tinggi }\end{array}$ \\
\hline 8 & $\begin{array}{l}\text { Pujian yang diberikan mempengaruhi } \\
\text { kinerja kearah yang lebih baik. }\end{array}$ & 50 & 29 & 4 & 0 & 0 & 366 & $\begin{array}{l}\text { Sangat } \\
\text { Tinggi }\end{array}$ \\
\hline 9 & $\begin{array}{l}\text { Terkadang saya mendapat pujian atas } \\
\text { kinerja saya dari pelanggan. }\end{array}$ & 46 & 32 & 5 & 0 & 0 & 373 & $\begin{array}{l}\text { Sangat } \\
\text { Tinggi }\end{array}$ \\
\hline \multicolumn{7}{|c|}{ Ucapan Terima Kasih } & 1116 & \\
\hline 10 & $\begin{array}{l}\text { Ucapan terima kasih dari atasan membuat } \\
\text { saya merasa dihargai. }\end{array}$ & 43 & 35 & 5 & 0 & 0 & 370 & $\begin{array}{l}\text { Sangat } \\
\text { Tinggi }\end{array}$ \\
\hline 11 & $\begin{array}{l}\text { Ucapan terima kasih dari atasan membuat } \\
\text { saya bersemangat dalam bekerja. }\end{array}$ & 54 & 29 & 0 & 0 & 0 & 386 & $\begin{array}{l}\text { Sangat } \\
\text { Tinggi }\end{array}$ \\
\hline 12 & $\begin{array}{l}\text { Ucapan terima kasih dari pelanggan } \\
\text { membuat saya merasa bahwa mereka puas } \\
\text { atas kinerja saya. }\end{array}$ & 36 & 39 & 8 & 0 & 0 & 360 & $\begin{array}{l}\text { Sangat } \\
\text { Tinggi }\end{array}$ \\
\hline \multicolumn{7}{|c|}{ Capaian variabel X } & 4477 & $\begin{array}{l}\text { Sangat } \\
\text { Tinggi }\end{array}$ \\
\hline
\end{tabular}

Sumber: Data Primer (2020)

Berdasarkan tabel diatas capaian variabel Insentif dengan dua indikator dan 12 item pertanyaan di mana tanggapan responden bervariasi sehingga nampak pada capaian setiap item pada variabel dengan capaian terendah pada Insentif materill sebesar1887 namun tetap berada pada kriteria sangat tinggi, dan dengan capaian variabel di mana secara keseluruhan capaian 4477 berada pada kriteria penilaian sangat tinggi dalam perspektif driver grab di kota Kupang berdasarkan keseluruhan penilaian driver grab terhadap insentif yang diterima. Berdasarkan tabel 12 dapat dilihat item pertanyaan dengan poit tertinggi pada indikator insentif materill yaitu pada item bonus, dapat disimpulkan bahwa sebagian besar responden memberikan jawaban setuju mengenai pertanyaan pertama yaitu perusahaan memberi bonus jika mampu mencapai target yang ditetapkan yakni sebanyak 55 responden, sedangkan untuk indikator insentif non-materill sendiri sebagian besar responden memberikan jawaban setuju pada item pertanyaan "Ucapan terima 
kasih dari atasan membuat saya bersemangat dalam bekerja" yakni sebanyak 54 responden. Kedua pertanyaan ini memiliki total poin yang sama yaitu 386 poin, artinya disini, selain insentif materil, insentif non materil juga mempengaruhi kinerja seseorang dalam bekerja, bahkan terkadang insentif non materill berupa ucapan terima kasih dan pujian atau penghargaan dalam bentuk lainnya lebih mempengaruhi kinerja seseorang dimana mereka merasa bahwa pekerjaan mereka dihargai. Hal ini sejalan dengan pendapat Sedarmayati 2001 yaitu, terkadang apa yang tidak dilihat tapi dirasakan ( lingkungan non-fisik) lebih berpengaruh dibandingkan bentuk fisik seperti uang dan lain-lain.

Tabel 13. Deskripsi Data Variabel Kinerja (Y)

\begin{tabular}{|c|c|c|c|c|c|c|c|c|}
\hline \multirow[t]{2}{*}{ No } & \multirow[t]{2}{*}{ Indikator /Item } & \multicolumn{5}{|c|}{ Skors } & \multirow[b]{2}{*}{ Jumlah } & \multirow{2}{*}{$\begin{array}{c}\text { Kriteria } \\
\text { Penilaian }\end{array}$} \\
\hline & & 5 & 4 & $\mathbf{3}$ & 2 & \begin{tabular}{|l|}
1 \\
\end{tabular} & & \\
\hline \multicolumn{7}{|c|}{ Kualitas Kerja } & 1108 & $\begin{array}{l}\text { Sangat } \\
\text { Tinggi }\end{array}$ \\
\hline 13 & $\begin{array}{l}\text { Saya selalu berusaha teliti dalam } \\
\text { bekerja. }\end{array}$ & 41 & 36 & 6 & 0 & 0 & 367 & $\begin{array}{l}\text { Sangat } \\
\text { Tinggi }\end{array}$ \\
\hline 14 & $\begin{array}{l}\text { Saya selalu mengutamakan kerapihan } \\
\text { dan kebersihan dalam bekerja. }\end{array}$ & 41 & 37 & 5 & 0 & 0 & 372 & $\begin{array}{l}\text { Sangat } \\
\text { Tinggi }\end{array}$ \\
\hline 15 & $\begin{array}{l}\text { Saya selalu memperhatikan standar } \\
\text { mutu pekerjaan saya. }\end{array}$ & 41 & 38 & 4 & 0 & 0 & 369 & $\begin{array}{l}\text { Sangat } \\
\text { Tinggi }\end{array}$ \\
\hline \multicolumn{7}{|c|}{ Kuantitas Kerja } & 1406 & $\begin{array}{l}\text { Sangat } \\
\text { Tinggi }\end{array}$ \\
\hline 16 & $\begin{array}{l}\text { Saya selalu menyelesaikan pekerjaan } \\
\text { dengan baik. }\end{array}$ & 34 & 28 & 21 & 0 & 0 & 345 & Tinggi \\
\hline 17 & $\begin{array}{l}\text { Saya berusaha mencapai target } \\
\text { jumlah/hasil pekerjaan yang } \\
\text { ditetapkan. }\end{array}$ & 32 & 25 & 11 & 14 & 1 & 321 & Tinggi \\
\hline 18 & $\begin{array}{l}\text { Setiap target yang saya dapatkan } \\
\text { menentukan bonus yang saya peroleh. }\end{array}$ & 42 & 36 & 4 & 1 & 0 & 368 & $\begin{array}{l}\text { Sangat } \\
\text { Tinggi }\end{array}$ \\
\hline 19 & $\begin{array}{l}\text { Saya selalu memperhatikan prosedur } \\
\text { teknis/kerja yang ditetapkan. }\end{array}$ & 47 & 30 & 5 & 1 & 0 & 372 & $\begin{array}{l}\text { Sangat } \\
\text { Tinggi }\end{array}$ \\
\hline \multicolumn{7}{|c|}{ Efektifitas Kerja } & 350 & $\begin{array}{l}\text { Sangat } \\
\text { Tinggi }\end{array}$ \\
\hline 21 & $\begin{array}{l}\text { Saya selalu berusaha menemukan } \\
\text { metode kerja yang efektif. }\end{array}$ & 28 & 45 & 10 & 0 & 0 & 350 & $\begin{array}{l}\text { Sangat } \\
\text { Tinggi }\end{array}$ \\
\hline \multicolumn{7}{|c|}{ Kemandirian } & 1448 & $\begin{array}{l}\text { Sangat } \\
\text { Tinggi }\end{array}$ \\
\hline 23 & $\begin{array}{l}\text { Saya tetap melakukan pekerjaan } \\
\text { dengan baik, walaupun banyak orang } \\
\text { mengkritik tentang pekerjaan saya. }\end{array}$ & 44 & 37 & 2 & 0 & 0 & 374 & $\begin{array}{l}\text { Sangat } \\
\text { Tinggi }\end{array}$ \\
\hline 24 & $\begin{array}{l}\text { Saya merasa bangga dan puas dengan } \\
\text { hasil pekerjaan saya. }\end{array}$ & 38 & 35 & 9 & 1 & 0 & 357 & $\begin{array}{l}\text { Sangat } \\
\text { Tinggi }\end{array}$ \\
\hline 25 & $\begin{array}{l}\text { Saya bekerja dengan sungguh-sungguh } \\
\text { tanpa bergantung pada orang lain. }\end{array}$ & 40 & 36 & 6 & 1 & 0 & 362 & $\begin{array}{l}\text { Sangat } \\
\text { Tinggi }\end{array}$ \\
\hline 26 & $\begin{array}{l}\text { Saya mampu mengatasi setiap } \\
\text { permasalahan dalam pekerjaan saya. }\end{array}$ & 45 & 30 & 4 & 3 & 1 & 355 & $\begin{array}{l}\text { Sangat } \\
\text { Tinggi }\end{array}$ \\
\hline \multicolumn{7}{|c|}{ Komitmen Kerja } & 763 & $\begin{array}{l}\text { Sangat } \\
\text { Tinggi }\end{array}$ \\
\hline 27 & $\begin{array}{l}\text { Saya selalu terlibat dalam setiap usaha } \\
\text { demi pencapaian tujuan perusahaan. }\end{array}$ & 52 & 27 & 4 & 0 & 0 & 380 & $\begin{array}{l}\text { Sangat } \\
\text { Tinggi }\end{array}$ \\
\hline
\end{tabular}




\begin{tabular}{|l|l|c|c|c|c|c|c|c|}
\hline No & \multicolumn{1}{|c|}{ Indikator /Item } & \multicolumn{3}{c|}{ Skors } & Kriteria \\
\cline { 3 - 8 } & $\mathbf{5}$ & $\mathbf{4}$ & $\mathbf{3}$ & $\mathbf{2}$ & $\mathbf{1}$ & Jumlah & \begin{tabular}{c} 
Penilaian \\
\hline
\end{tabular} \\
\hline $\begin{array}{l}\text { Saya selalu mendahulukan kepentingan } \\
\text { konsumen dari pada kepentingan } \\
\text { pribadi. }\end{array}$ & 55 & 24 & 4 & 0 & 0 & 383 & $\begin{array}{l}\text { Sangat } \\
\text { Tinggi }\end{array}$ \\
\hline Capaian variabel Y & & & & & & & & \\
\hline
\end{tabular}

Sumber: Data Primer (2020)

Berdasarkan tabel diatas capaian variabel Kinerja dengan lima indikator dan 14 item pertanyaan di mana tanggapan responden bervariasi sehingga nampak pada capaian setiap item pada variabel dengan capaian terendah pada indikator efektifitas kerja sebesar 350 dan berada pada kriteria sangat tinggi, indikator efektifitas rendah dikarenakan hanya terdapat 1 Item pertanyaan saja, sedangkan untuk indikator lainnya berada pada kriteria sangat tinggi. Namun tetap pada capaian variabel di mana secara keseluruhan capaian 5075 berada pada kriteria penilaian sangat tinggi dalam perspektif driver grab di kota kupang berdasarkan keseluruhan penilaian driver grab terhadap kinerja yang diterima, berarti insentif terhadap kinerja memiliki pengaruh terhadap kinerja dari driver grab di kota Kupang. Berdasarkan tabel diatas dapat dijelaskan bahwa kinerja pengemudi grab bike dikota kupang dipegaruhi oleh insentif yang diterima baik insentif materill maupun insentif non-materill, dimana insentif merupakan salah satu upaya memotivasi karyawan demi meningkatkan kinerja, hal ini sesuai dengan pendapat Wibowo (2012) menyebutkan bahwa Insentif mempunyai hubungan dengan kinerja karyawan, karena setiap pekerja yang telah memberikan kinerja terbaiknya pasti mengharapkan imbalan disamping gaji atau upah sebagai tambahan berupa insentif atas prestasi yang telah diberikannya terhadap perusahaan.

\section{Analisis Regresi Linear Sederhana}

Analisis regresi linear sederhana digunakan untuk mengetahui variabel independen (X) terhadap variabel dependen $(\mathrm{Y})$ dengan jumlah variabel bebas maupun terikat tidak lebih dari satu.

Tabel 14. Hasil Analisis Linear Regresi Sederhana

\begin{tabular}{|c|c|c|c|c|c|}
\hline \multirow{2}{*}{ Model } & \multicolumn{2}{|c|}{ Unstandardized Coefficients } & \multirow{2}{*}{$\frac{\text { Standardized Coefficients }}{\text { Beta }}$} & \multirow[t]{2}{*}{$\mathbf{T}$} & \multirow{2}{*}{ Sig. } \\
\hline & B & Std. Error & & & \\
\hline (Constant) & 47,057 & 5,418 & & 8,685 & 0,000 \\
\hline INSENTIF_X & 0,444 & 0,100 & 0,443 & 4,450 & 0,000 \\
\hline
\end{tabular}

a. Dependent Variable: KINERJA_Y

Sumber: Data Primer (2020)

Hasil analisis diatas dapat dirumuskan persamaan sebagai berikut:

$$
Y=47,057+0,444 X
$$

Persamaan regresi diatas dapat dijelaskan sebagai berikut :

1. Nilai konstanta a sebesar 47,057 memiliki makna jika nilai insentif sebesar 0 (tidak ada) maka nilai kinerja adalah sebesar 47,057.

2. Koefisien regresi (b) dari variabel insentif sebesar 0,444 satuan memiliki makna jika insentif dinaikan sebesar 1 satuan maka kinerja akan mengalami peningkatan sebesar 0,444 satuan. 


\section{Hipotesis (Uji t)}

Uji t digunakan untuk mengukur seberapa jauh pengaruh variabel bebas secara individual dalam menerangkan variasi variabel terikat. Hasil uji t dalam penelitian ini yaitu:

Tabel 15. Hasil Tabel Uji t

\begin{tabular}{|c|c|c|c|c|c|}
\hline \multirow[t]{2}{*}{ Model } & \multicolumn{2}{|c|}{ Unstandardized Coefficients } & \multirow{2}{*}{\begin{tabular}{|c|} 
Standardized Coefficients \\
Beta
\end{tabular}} & & \multirow[t]{2}{*}{ Sig. } \\
\hline & B & Std. Error & & & \\
\hline $\begin{array}{r}(\mathrm{C} \\
\mathrm{INS}\end{array}$ & $\begin{array}{r}47,057 \\
0,444\end{array}$ & 0,100 & 443 & $\begin{array}{l}8,685 \\
4,450\end{array}$ & \\
\hline
\end{tabular}

a. Dependent Variable: KINERJA_Y

Sumber: Data Primer (2020)

Adapun langkah-langkah pengujian sebagai berikut:

1. Menentukan hipotesis

$\mathrm{Ha}$ : Diduga Insentif berpengaruh secara signifikan terhadap kinerja driver Grab di Kota Kupang

Ho : Diduga Insentif tidak berpengaruh secara signifikan terhadap kinerja driver Grab di Kota Kupang

2. Menentukan thitung

Dari tabel 4.5 diperoleh output $t_{\text {hitung }}$ sebesar 4,450 dengan signifikansi ( $p$ value ) sebesar 0,000

3. Menentukan $t_{\text {tabel }}$

Mencari $\mathrm{t}_{\text {tabel }}$ dengan derajat kebebasan $\mathrm{df}=\mathrm{n}-\mathrm{k}=83-2(\mathrm{n}=$ jumlah sampel, $\mathrm{k}=$ jumlah variabel ) yaitu 1,663

4. Kriteria pengujian

Jika $t_{\text {hitung }}>t_{\text {tabel }}$ atau signifikansi lebih kecil dari alpha $(p<\alpha)$ maka Ho ditolak dan Ha diterima

Jika $t_{\text {hitung }} \leq t_{\text {tabel }}$ atau signifikansi lebih besar dari alpha $(p>\alpha)$ maka Ho diterima dan Ha ditolak

5. Membandingkan $t_{\text {hitung }}$ dengan $t_{\text {tabel }}$ dan signifikansi dengan alpha $t_{\text {hitung }}(4,450)>t_{\text {tabel }}$ ( 1,663) dan signifikansi ( 0,000$)$ lebih kecil dari alpha $(\alpha=0,05)$.

6. Keputusan

Nilai $t_{\text {hitung }}>t_{\text {tabel }}$ sehingga Ho ditolak dan Ha diterima. Artinya bahwa ada pengaruh secara signifikan antara Insentif dengan Kinerja.

\section{Koefisien Determinasi $\left(\mathbf{R}^{2}\right)$}

Nilai koefisien Determinasi $\left(\mathrm{R}^{2}\right)$ menunjukkan presentase pengaruh semua variabel independen terhadap variabel dependen.

Tabel 16. Hasil Uji Determinasi

\begin{tabular}{|c|r|r|r|r|}
\hline Model & R & R Square & $\begin{array}{c}\text { Adjusted R } \\
\text { Square }\end{array}$ & $\begin{array}{c}\text { Std. Error of } \\
\text { the Estimate }\end{array}$ \\
\hline 1 & $0,443^{\mathrm{a}}$ & 0,196 & 0,187 & 4,068 \\
\hline
\end{tabular}

a. Predictors: (Constant), INSENTIF_X

Sumber: Data Primer (2020)

Berdasarkan tabel diatas, nilai $R$ square sebesar 0,196 artinya variabel bebas mampu menjelaskan variabel terikatnya sebesar 19,6\% dan sisanya sebesar 80,4\% dijelaskan oleh faktorfaktor lainnya diluar dari variabel bebas yang dipakai dan dijelaskan dalam penelitian ini, seperti kemampuan dan keahlian, lingkungan kerja, motivasi kerja, kepemimpinan, dan gaya 
kepemimpinan (Kasmir, 2016). Faktor - faktor lainnya seperti kemampuan mereka, motivasi, dukungan yang diterima, keberadaan pekerjaan yang mereka lakukan dan hubungan mereka dengan organisasi (Mathis dan Jackson, 2016).

\section{Pembahasan}

Berdasarkan hasil analisis deskriptif menunjukan bahwa insentif pada pengemudi Grab Bike di kota Kupang berada pada kriteria sangat tinggi dimana insentif yang diterima mempengaruhi kinerja mereka atau dengan kata lain Insentif berpengaruh positif terhadap kinerja. Hasil penelitian ini sejalan dengan hasil penelitian Bengngu, et. al, (2018) pada mitra grab di Kupang, dimana insentif yang diperoleh mitra Grab Kupang dapat meningkatkan produktivitas karena faktor material masih merupakan faktor utama dalam menarik minat seseorang untuk dapat bekerja. Pemberian insentif yang tepat dan sesuai dapat mendorong semangat kerja karyawan dalam mencapai tujuan perusahaan, hal ini sesuai dengan pendapat Handoko (2014) yang mengatakan bahwa insentif merupakan perangsang yang ditawarkan kepada karyawan untuk melaksanakan kerja sesuai atau lebih tinggi dari standar-standar yang telah ditetapkan. Insentif mempunyai hubungan positif kinerja karyawan, dimana setiap pekerja yang telah memberikan kinerja terbaiknya pasti mengharapkan imbalan disamping gaji atau upah sebagai tambahan berupa insentif atas prestasi yang telah diberikan terhadap perusahaan (Wibowo, 2012). Dengan demikian apabila organisasi dapat memberikannya maka akan meningkatkan motivasi, partisipasi dan membangun saling pengertian dan saling percaya antara atasan dengan para pekerja. Dengan adanya pemberian insentif yang tepat karyawan akan termotivasi sehingga kinerjanya semakin baik.

Hasil penelitian ini menunjukkan bahwa Kinerja para pengemudi grab bike di kota kupang dipengaruhi oleh insentif yang didapat, baik insentif materill maupun insentif nonmaterill. Insentif materill dan insentif non-materill dapat meningkatkan kinerja pengemudi grab bike dimana dengan adanya pemberian insentif para pengemudi merasa diperhatikan dan dihargai, sehingga mereka dapat melaksanakan tugasnya semaksimal mungkin. Insentif sangat diperlukan untuk memacu kinerja para pengemudi grab bike agar selalu berada pada tingkat optimal sesuai kemampuan masing-masing. Peran insentif cukup besar dalam membentuk karyawan potensial. Pemberian insentif yang tinggi dan relevan pada saat karyawan bekerja akan berpengaruh terhadap kinerja karyawan. Pemberian insentif dirasa sangat penting bagi para pengemudi mengingat terlalu banyak kebutuhannya masing-masing sehingga dengan adanya pemberian insentif diharapkan dapat meningkatkan kesejahteraan hidup para pengemudi grab bike. Hasil uji determinasi $\left(\mathrm{R}^{2}\right)$ yang menunjukan bahwa variabel insentif mempengaruhi variabel kinerja dengan nilai pengaruhnya relatif lemah. Faktor lainnya yang mempengaruhi kinerja yaitu kemampuan dan keahlian, lingkungan kerja, motivasi kerja, kepemimpinan, dan gaya kepemimpinan (Kasmir, 2016), atau faktor-faktor lain seperti kemampuan mereka, motivasi, dukungan yang diterima, keberadaan pekerjaan yang mereka lakukan dan hubungan mereka dengan organisasi (Mathis dan Jackson, 2016).

\section{PENUTUP \\ Simpulan}

Kesimpulan yang dapat diambil dari penelitian ini adalah Hasil analisis deskripsi menggunakan rentang skor diperoleh variabel Insentif dan Kinerja berada pada kategori sangat tinggi. Pemberian insentif baik materill maupun insentif non-materill sangat efektif dalam meningkatkan kinerja para pengemudi grab bike di kota Kupang, dimana dengan adanya sistem insentif di luar gaji atau pendapatannya, mereka merasa diperhatikan dan dihargai oleh perusahaan. Pada hasil pengujian hipotesis dengan menggunakan uji $\mathrm{t}$ membuktikan bahwa insentif berpengaruh positif dan signifikan terhadap kinerja pengemudi Grab Bike di kota Kupang, hasil ini diperkuat oleh hasil analisis determinasi yang menunjukan adanya pengaruh insentif terhadap kinerja pengemudi Grab Bike di Kota Kupang.

\section{Saran}


Berdasarkan hasil penelitian diatas, maka saran yang diajukan adalah diharapkan perusahaan Grab dapat mempertahankan serta meningkatkan pemberian insentif kepada para pengemudi agar kinerja yang diberikan lebih maksimal. Bagi peneliti selanjutnya, diperlukan penelitian lebih lanjut dengan menambah faktor-faktor lain diluar Insentif yang ikut mempengaruhi kinerja pengemudi grab bike, seperti lingkungan kerja, motivasi kerja, kemampuan mereka, motivasi, dukungan yang diterima, keberadaan pekerjaan yang mereka lakukan dan hubungan mereka dengan organisasi.

\section{REFERENSI}

Awallunnisa, F., \& Agustin, R. (2015). Kecerdasan Emosional (EQ) Dengan Kinerja Perawat Dalam Pendokumentasian Asuhan Keperawatan. THE SUN, 2(1).

Bengngu, Allen., Amtiran, Paulina Yuritha., \& Fanggidae, Rolland Epafras. (2018). Impact of Part Time, Flextime and Reward on Productivity (Case Study on Grab Online Transportation Partners in Kupang City). Proceedings of the International Conference on Tourism, Economics, Accounting, Management, and Social Science (TEAMS 2018). Atlantis Press.

Dessler, G. (2015). Manajemen Sumber Daya Manusia. Jakarta: Selemba Empat.

Ghozali. (2012). Aplikasi Analisis Multivariate dengan Program IBM SPSS. Yogyakarta: Universitas Diponegoro

Gorda. (2012). Manajemen Sumber Daya Manusia. Edisi Revisi. Denpasar: Astabrata Bali bekerja sama dengan STIE Satya Dharma Singaraja Grafindo Persada.

Handoko. (2014). Manajemen Personalia Dan Sumber Daya Manusia. Yogyakarta: BPFE.

Hasibuan. (2014). Manajemen Sumber Daya Manusia, Cetakan keempatbelas, Jakarta ,Penerbit : Bumi Aksara.

Hidayat, M. (2014). Faktor-faktor yang Mempengaruhi Tingkat Partisipasi Angkatan Kerja di Sulawesi Selatan Tahun 2004-2012 (Doctoral dissertation, UIN Alauddin Makassar).

Umar. ( 2014). Metode Penelitian Untuk Tesis dan Bisnis. Jakarta : Grafindo Persada.

Kasmir. (2016). Manajemen Sumber Daya Manusia (Teori Dan Praktik ). Jakarta : PT Raja Grafindo.

Mathis Robert L \& John H. Jackson, (2016). Manajemen Sumber Daya Manusia. Buku 1, Alih Bahasa: Jimmy Sadeli dan Bayu. Prawira Hie. Jakarta: Salemba Empat.

Moeheriono. (2012). Pengukuran Kinerja Berbasis Kompetensi. Jakarta: Raja Grafindo Persada.

Rivai. (2015). Manajemen Sumber Daya Manusia untuk Perusahaan dari Teori ke Praktik, Jakarta:PT Raja Grafindo Persada

Robbins.. (2013). Perilaku Organisasi Edisi 16. Jakarta: Salemba Empat.

Sarwoto (2012). Dasar-Dasar Organisasi dan Manajemen. Cetakan keenambelas. Penerbit Ghalia Indonesia.

Siagian. (2012). Kiat Meningkatkan Produktivitas Kerja. Jakarta : Raneka Cipta.

Simamora, Henry (2015). Manajemen Sumber Daya Manusia. Yogyakarta: STIEY

Sirait. (2012). Memahami Aspek-Aspek Pengelolaan Sumber Daya Manusia Dalam Organisasi. Jakarta: Grasindo.

Sugiyono. (2014). Metode Penelitian Pendidikan Pedekatan Kuantitatif dan R\&D. Bandung : Alfabeta

Sugiyono. (2013). Metode Penelitian Pendidikan Pendekatan Kuantitatif, Kualitatif dan R\& D. Bandung : Alfabeta.

Sugiyono. (2012). Memahami Penelitian Kualitatif. Bandung : ALFABETA.

Syamsuddinnor. (2014). Pengaruh Pemberian Pemberian Insentif Dan Disiplin Kerja Terhadap Kinerja Karyawan Pada PT Ben Line Agencies (BLA) Banjar Masin. Jurnal Socioscientia, 6 (1), 1-44. Diperoleh tanggal 7 November 2014.

Wasisto. E. (2014). Pengaruh Insentif Terhadap Motivasi Kerja Dan Kinerja Pegawai STIE Adi Unggul Bhirawa Surakarta. Advance Edisi Februari 2014. 
Wibowo. (2012). Manajemen Kinerja. Edisi Ketiga . Jakarta : Rajawali PersYogyakarta : BPFE. 